\title{
Employee Perceptions of the Electronic Procurement System (EPS) and Rate of Adoption of EPS by the Federal Public Hospitals in Edo State of Nigeria Based on the Diffusion of Innovations Theory
}

\section{Omoregbe Omorodion* and Osifo, Samuel Jesuorobo}

Department of Business Administration, University of Benin, Nigeria

\section{Abstract}

This study investigated the perception of electronic procurement (eprocurement) system and rate of adoption in the federal public hospitals in Edo State of Nigeria. The rate of adoption is premised on Rogers' diffusion of innovations approach using the process of innovation characteristics: relative advantage, trialability, compatibility, observability, and complexity of e-procurement system to evaluate the rate at which organizations adopt new innovations. The degrees of difficulties faced by the hospitals in the adoption of eprocurement system and the benefits of the e-procurement system adoption were also studied. The study used convenience sampling technique to select 45 management staff of procurement departments of three federal public hospitals spread across Edo State. The Ordinary Least Squares (OLS) technique was used to estimate the model that was developed. The findings showed that the greatest challenge faced by the hospitals in the adoption of EPS was the lack of e-procurement system infrastructure due to inadequate funding. On the benefits of adopting EPS in the hospitals, the findings showed that reduction in wastage in the time lost in the process of procurement of materials and mistakes that emanate from retyping

\footnotetext{
* Corresponding should be addressed to Dr Omoregbe Omorodion, Department of Business Administration, University of Benin, Nigeria
}

Email: osifosamuel@gmail.com

https://orcid.org/0000-0002-9194-6453

(Received 15th September 2020; Revised 17th December 2020; Accepted 20th December 2020 (C) OUSL) 
and exchange of documents, increased efficiency of business operations were the major advantages of e-procurement system adoption. The regression results demonstrated that all the exogenous variables were significant and positively influenced the rate of adoption in the federal public hospitals in Edo State, except complexity of e-procurement system that had a significant negative predictor on management of the hospitals' policy decision to adopt electronic procurement system. The relative advantage of eprocurement system score was the best predictor of respondents' attitudes toward rate of adoption of new innovations in the hospitals. It is therefore recommended that innovations that are simple and user-friendly in design should be adopted. Simpler the innovation, quicker the adoption by the employees of an organization. Management of the hospitals' procurement department should deploy the necessary information technology infrastructure, personnel with requisite expertise, digital skills, and knowledge for the successful adoption of the e-procurement system.

Keywords: Compatibility, Complexity, Electronic Procurement System, Rate of Adoption, Relative Advantage, Trialability, Diffusion of Technological Innovation Theory.

JEL CODES: C42, H57, L32, L86

\section{Introduction}

The role of the healthcare sector in nation building cannot be overemphasized. It is the prime aspect of a nation's institutions that ensures the wellbeing of every citizen. The provision of basic healthcare is a key element in the promotion of broad-based socioeconomic growth and development of a nation. The healthcare industry in Nigeria has been evolving over the years and confronted daunting challenges in the face of profitable opportunities (Ikponmwosa \& Omoregbe, 2018). Ikponmwosa and Omoregbe (2018) emphasized that these challenges typically manifest in terms of poor deployment of infrastructure/equipment, inadequate access to sustainable financing, inflow of sub-standard and counterfeit drugs, poor remuneration of healthcare practitioners, unfavourable government policies and implementation, and lopsided health insurance facilities, among other things. To surmount these challenges, federal public hospitals in the country must be efficient in their use of resources and benchmark their performance against that 
of their peers across the globe. Hence, the need for the healthcare sector in the country to examine areas that can lead to operational performance in planning and executing strategies that will continuously make them relevant in the face of competition from other business enterprises cannot be overstated.

With the advent of the Internet and today's global competitive healthcare institutions, the delivering of quality and innovative services to clients by federal public hospitals in Nigeria is a must for their continuous survival. Consequently, in order to improve business efficiency, many healthcare institutions today are shifting their operational mode of performing businesses from the old-style procurement system to the adoption of electronic procurement system (Davila, Gupta, \& Palmer, 2003). The consequences of the continuous use of traditional procurement system range from lack of access to swift information, lack of continuous replenishment supply model, etcetera. The increasing awareness and exposure to electronic procurement mechanisms by public officers cannot be underscored, hence, the need for a change in the procurement systems. The adoption of Electronic Procurement System (EPS) in the healthcare institutions has the potential benefits to increase service firms' competitive advantages on the basis of improved clients' satisfaction with ground-breaking ideas, reduction in the total cost of material acquisition, timely delivery of materials, improved profitability, elimination of paperwork, improved suppliers' relationships with the healthcare institutions management, enhanced operational efficiency, and improved procurement process transparency/accountability (Davila et al, 2003; Trkman \& McCormack, 2010; Matunga, Nyanamba, \& Okibo, 2013).

However, the hesitation to adopt EPS by public hospital procurement practitioners stems from lack of availability of the facilities necessary for e-procurement system adoption (Matunga et al, 2013). Most public hospitals in Nigeria use the stand-alone computers that run few applications / packages such as the use of word processing and spread sheeting packages. There is the seeming difficulty in the use of new innovations by employees, unawareness of clear-cut anticipated benefits of the new innovations, among others (Min \& Galle, 2003; Matunga et al, 2013). 
Diffusion of Innovations Theory (DIT) is an adoption model for understanding and examining the rate of adoption of novel innovations, such as the electronic procurement system (Dibra, 2015). The theory clarifies "the process by which an innovation is communicated through certain channels over time among members of a social system" (Rogers, 2003:5). According to Rogers, the characteristics of process of innovation assist to clarify different influencing attributes that will necessitate the adoption of innovation in an organization. Against this backdrop, knowledge of the factors affecting e-procurement system and its rate of adoption in the federal public hospitals in Edo State of Nigeria becomes critical. Hence, the study examined the perception of electronic procurement system and rate of adoption in the federal public hospitals in Edo State of Nigeria premised on Rogers' diffusion of innovations theory. Also studied were the difficulties and benefits of the e-procurement system adoption in the federal public hospitals in Edo State of Nigeria.

\section{Statement of the Research Problem}

The advent of the Internet has made e-businesses gain increased dominance and enhanced competitiveness in the global healthcare sector (Matunga et al, 2013). Despite the current trend towards eprocurement system practices as a cost-effective way in creating more values to customers/clients, when it comes to reaching suppliers and business allies in a way to gain market share and competitive advantage, many hospitals in Nigeria are still trailing behind in its adoption and implementation.

In recent times, there have been a number of criticisms on the mode of procurement process in the federal public hospitals in Nigeria. Complaints related to procurement practices in the federal public hospitals in Nigeria stem from poor handling of procurement information about the procurement process thus leading to excessive corruption, delay in timely supply of materials, unnecessary exploitation of clients/contractors through unsolicited gratifications, issues of poor tendering, delay in payment of suppliers due to the deferment in granting permissions for the supply of materials (Ojo \& Gbadebo, 2014; Bodunrin, 2016). To this end, the use of traditional procurement system by the hospitals leads to slow service delivery. 
Furthermore, as the common experiences in Nigeria suggest most federal public hospitals do not have the facilities and capacities for carrying out trusted and secured EPS. These hospitals are hindered by poor network service, which at times, is occasioned by the incompetence of the technical team, lack of accountability and openness in the process of procurement for goods (Ojo \& Gbadebo, 2014; Bodunrin, 2016). Thus, these challenges have seemingly and practically made it difficult for federal public hospitals in Nigeria to have appropriate technique in consulting, bidding, and contracting the supply of materials to contractors. The absence of an electronic procurement initiative in the federal public healthcare sector in Nigeria has led to poor efficiency in achieving the best deal of the supply contract in the healthcare service delivery and has thus caused low suppliers' satisfaction, and possibly threatened competitive advantage of federal public hospitals in Nigeria (Bodunrin, 2016). The increasing competitiveness in healthcare sector across the globe means that federal public hospitals in Nigeria need to brace up towards the maximization of productivity amongst others if they are to succeed.

A review of the outcome of studies that apply different theories on the adoption of innovations in the organizations and subsequent criticisms have turned out been inconclusive. This is due to the fact that the research results have been unpersuasive, inconsistent, and branded with insufficient explanations (Robinson, 2009; Dibra, 2015). In pursuit of a suitable model for the determination of explanatory attributes for the likelihood of the adoption of new innovations such as the use of EPS in the federal public hospitals in Nigeria, the Rogers' theory of diffusion of innovations offers the best explanation (Sahin, 2006; Dibra, 2015). Corroborating this fact, premised on the strengths and weaknesses associated with the different theoretical models analyzed in explaining the influencing factors for the implementation of new innovations, Robinson (2009:1) emphasized that "the theory of Rogers has been tested through more than 6,000 research studies, which makes it very reliable".

However, there is a dearth of studies that have addressed the perception of e-procurement initiative and its rate of adoption in the federal public hospitals in Nigeria based on Rogers' diffusion of 
innovations approach. The implementation of electronic procurement initiative in the federal public hospitals in Nigeria nonetheless will be worthy and appropriate in view of its influence in other areas of the economy (Dibra, 2015). Against this background, a study on the EPS influencing factors on rate of its adoption, challenges faced in the course of acceptance of electronic procurement mechanism as well as an appraisal of the degree of benefits associated with the adoption of EPS in the federal public hospitals in Edo State of Nigeria is thus essential. The findings of the study will contribute to policy debate on e-procurement system for the Nigerian healthcare sector. Thus, this study draws motivation from the quest to add to knowledge in the space of technological adoption in the federal public healthcare sector in Nigeria.

\section{Review of Literature}

Minahan and Degan (2001) stated that electronic procurement system is the use of the Internet to perform procurement process. In the views of Wu, Zsidisin, and Ross (2007), the EPS is the use of automated system to facilitate supply of goods over the Internet. In other words, EPS entails purchasing and selling of products over the Internet between businesses. It is an electronic platform that enables organizations link directly with business allies and contractors to enable the process of procurement of materials. To this end, EPS is a business strategy by business enterprises to manage all business dealings, such as bids, inquiries and responses, and pricing for products and services. These business relations are related to the supply of materials for the organization. The purchases of products and services over the Internet involve a number of processes, which include searching, information, sourcing, selecting, settlement, negotiation, ordering, receipt, and after-sales/management of supplies, among others.

Matunga et al (2013) posited that electronic procurement system is quicker when it comes to sending documents as compared to the brick-and-mortar form of transferring tender documents through post office. They emphasized that the use of EPS results in enhanced order tracking and tracing of documents because EPS ensures easier tracing of orders and making of necessary corrections in the event of errors been detected, reduction in time to source for materials, etcetera. Matunga et al (2013) are of the view that with these 
aforementioned benefits of EPS, developing countries seem to be lagging behind in embracing this innovation.

One of the well-known approaches to the explanation of the rate of adoption of innovations in the organization is the Rogers (2003) innovation-diffusion theory. Rogers (2003:221) stated that the rate of adoption of innovation is "the relative speed with which an innovation is adopted by members of a social system." Rogers (2003:232) is of the view that the innovation-diffusion process is "an uncertainty reduction process" that affects the rate of adoption of innovations in the organizations. Thus, Rogers proposed five features of innovation diffusion that can influence rate of adoption of innovation in an organization: relative advantage, trialability, complexity, compatibility, and observability. He affirmed that "individuals' perceptions of these characteristics are significant predictors of the rate of adoption of innovations" (Rogers, 2003:219).

\section{Perceived Relative Advantage of E-procurement System Innovation and Rate of Adoption}

Rogers (2003:229) defined relative advantage of an innovation as "the extent to which a particular group of users perceive innovation as better than the idea, or practice it replaces." Rogers stated that the higher the seeming relative advantages of innovations by business enterprise, the quicker the degree of its adoption. Dibra (2015) posited that the extent of the comparative advantage of an innovation can be determined according to economic, social status, ease, and desire of using the innovations. In the same vein, Beatty, Shim, and Jones (2001:339) affirmed that "an organization will only adopt an innovation if it will resolve existing problems or provide new business opportunities". They added that the relative advantage of adopting an innovation results in improvement in business performance, such as reduction in transaction costs, enhanced cash flow, improved customer services, and enhanced operational efficiency of the firm. Nevertheless, Robinson (2009:2) pointed out that "there is no absolute rule as to who is included in the relative advantage of the use of an innovation. It depends on individual perceptions and the needs of the user group." The value of the operational efficiency of innovations should be clearly defined and stated in order for management and staff of the business enterprise to use the technology. 
Hypothesis one: the relative advantage of electronic procurement system has a positive significant relationship with the rate of adoption in the federal public hospitals in Edo State of Nigeria.

\section{Perceived Compatibility of E-procurement System Innovation and Rate of Adoption}

In the views of Rogers (2003:15), "compatibility of an innovation is the degree to which innovation is perceived as consistent with existing values, past experiences, and needs of potential adopters." Rogers further stated that innovations that are not in harmony with the social configuration, ideals, personal life, and standards of the practices of the employees will not be adopted as fast as expected. In the same vein, Beatty et al (2001:340) emphasized that "business enterprises are more likely to adopt a new innovation if it is compatible or consistent with their value system, existing infrastructure, business processes, and culture". It is worthy to note that each innovation adopted in the organization has the likelihood to influence employees' views about its operational efficiency. Thus, if an innovation is compatible with employees' desires, doubt about the workability of the innovation will decline and the rate of its adoption will increase. For Rogers (2003), compatibility of innovation with employee needs will positively affect the individual's rate of adoption.

Hypothesis two: compatibility of electronic procurement system has a positive significant relationship with the rate of adoption in the federal public hospitals in Edo State of Nigeria.

\section{Perceived Complexity of E-procurement System Innovation and Rate of Adoption}

Rogers (2003:15) defined complexity of an innovation as "the degree to which innovation is perceived as relatively difficult to understand and use." In other words, if employees of business enterprises feel that innovation is simpler to understand and they do not have to undergo new skills in order to use the innovation, it is likely to be adopted faster. Hence, if an employee of the business enterprise possesses a reasonable skills, knowledge, and expertise the lesser the complexity of the innovation. Rogers (2003) is of the view that when innovations are complex to understand and use, the employees of the organizations will have to develop new skills. 
Hypothesis three: complexity of electronic procurement system has a positive significant relationship with the rate of adoption in the federal public hospitals in Edo State of Nigeria.

\section{Perceived Trialability of E-procurement System Innovation and Rate of Adoption}

In the views of Rogers (2003:16), "trialability of an innovation is the extent to which innovation can be proved on limited evidence before it can really convince most potential adopters". To this end, it refers to the rate in which innovation can be tried or verified on a partial basis. Dibra (2015) argued that if innovation cannot be verified, it has less likelihood of acceptance by the adopters. Innovations that can be verified signify less doubt to employees of the organization who will consider it for adoption. Rogers (2003:177) maintained that "if an innovation has a partial trial basis, it is usually adopted more quickly, since most individuals first want to try the innovation in their own situation and then come to an adoption decision."

Hypothesis four: trialability of electronic procurement system has a positive significant relationship with the rate of adoption in the federal public hospitals in Edo State of Nigeria.

\section{Perceived Observability of E-procurement System Innovation and Rate of Adoption}

Rogers (2003:16) affirmed that observability of innovation is "the degree to which the results of an innovation are more visible than others." Innovation observability is the distinctiveness of the results of innovation been more noticeable than other related innovations. Thus, if the outcomes of an innovation are easier to be observed by the employees of the organization, the more likely will the innovation be adopted. According to Rogers (2003:15), "this helps potential adopters to know how valuable the innovation is beforehand due to observable results by early adopters of such innovation." Dibra (2015) posited that such an innovative distinction can encourage discussions with other employees who often depend on assessment information about the innovation. Rogers argued that innovations that offer more visibility will be adopted sooner than other innovations. 
Hypothesis five: observability of electronic procurement system has a positive significant relationship with the rate of adoption in the federal public hospitals in Edo State of Nigeria.

\section{Empirical Review}

Vaidya, Sajeev, and Callender (2006) examined factors that can affect the success of e-procurement system implementation in the public sector. Significant variables of critical success factors were identified in the study. Management factors were revealed in the study as the most significant factors for successful e-procurement system. It recommended that if managements of the public sector organizations are to assist in the advancement of e-procurement in organizations, a wider discussion and agreement on what defines the pertinent eprocurement system critical success factors in the organizations should be made as a policy.

Matunga et al (2013) assessed the extent to which electronic procurement system influences efficient procurement in public hospitals in Kisii, Kenya. The study used a sample of five hospitals. The study made use of e-quotations, e-tendering, and e-sourcing as the major EPS variables. It was established that the utmost difficulties confronted when using EPS was lack of capital, inability to manage change programs, and inadequate training of staff on the use of new innovations. It established that public hospitals have implemented some of the e-procurement practices irrespective of the barriers that follow the implementation.

Dibra (2015) studied different theoretical models that can influence organizations to implement sustainable tourism practices, giving their strengths and weaknesses. The study revealed that workable tourism development is a requirement of time. It established that Rogers' approach on diffusion of innovation is the suitable model in the examination of attributes that influence the implementation of sustainable tourism practices. It recommended that stakeholders associated with tourism should be concerted in ensuring sustainable tourism development. 


\section{Methodology}

The study examined the perception of electronic procurement system and rate of adoption in the federal public hospitals in Edo State of Nigeria based on Rogers' diffusion of innovations approach. The survey research design was adopted for the study. Primary data was used and data collected through field survey with the help of questionnaire. The data were obtained between May, 2020 and August, 2020.

The study population of interest was all the management staff of the procurement department of the respective federal public hospitals in Edo State of Nigeria. The sample of the study comprised all the three (3) procurement management staff of University of Benin Teaching Hospital, Benin City, Federal Neuro-Psychiatric Hospital, Uselu, and Irrua Specialist Teaching Hospital, Irrua, all in Edo State of Nigeria. The management staff was involved because they make policy decisions pertaining to procurement and demands for supplies for the hospitals. Due to their knowledge and experiences, they are assumed to be conversant with the management of the hospitals' operations and procurement procedures, and therefore, can easily provide the needed information for the study. The estimated number of the management staff of the procurement departments of the respective federal public hospitals that form the target population for the study was forty-five (45) as at August, 2020. Due to the smallness in size of the population, the study made use of the forty-five (45) respondents as the sample size.

The questionnaire used for the study comprised of two main segments. The first section is the general profile of the respondents and the other section consists of specific statements patterned to measure the management staff's knowledge, expertise, and involvement in line with the management of the hospitals' procurement operations. The questionnaire's data items were measured using five points Likert scales: $5=$ strongly agree, $4=$ agree, $3=$ undecided, $2=$ disagree, and $1=$ strongly disagree. Descriptive and inferential statistics were used to analyze the collected data. The data were tested at five (5) per cent level of significance using the Ordinary Least Squares estimation technique. 


\section{Validity and Reliability of Research Instrument}

To ensure validity of the questionnaire designed, copies of the questionnaire were given to senior colleagues in the research area to critically examine the applicability of the questions. A pilot study was performed by testing and pre-testing the research instrument with a copy given to twenty (20) selected respondents among management staff of the different federal public hospitals in Edo State of Nigeria. Feedbacks were revised and questions were then harmonized. The final form of the research instrument comprised of twenty-four (24) closed ended questions for the inferential statistics.

To test the questionnaire for reliability, the researchers used Cronbach's alpha coefficient test as an analytical measure to ascertain the internal consistency of the items. The outcome of the reliability test is presented in Table 1 . The Cronbach's alpha value for each construct as shown in the Table 1 is above 0.6. This implies that the research instrument is reliable and can be depended upon to elicit the needed information from the respondents (Nunnally \& Bernstein, 1994).

Table 1: Cronbach Alpha Values

\begin{tabular}{|l|c|c|}
\hline \multicolumn{1}{|c|}{ Variables } & $\begin{array}{c}\text { Number of } \\
\text { Items }\end{array}$ & $\begin{array}{c}\text { Cronbach } \\
\text { Alpha }\end{array}$ \\
\hline $\begin{array}{l}\text { Relative odvantage of electronic } \\
\text { procurement system }\end{array}$ & 4 & 0.7017 \\
\hline $\begin{array}{l}\text { Compatibility of electronic procurement } \\
\text { system }\end{array}$ & 4 & 0.7812 \\
\hline $\begin{array}{l}\text { Complexity of electronic procurement } \\
\text { system }\end{array}$ & 4 & 0.7565 \\
\hline $\begin{array}{l}\text { Obsevability of electronic procurement } \\
\text { system }\end{array}$ & 4 & 0.7934 \\
\hline $\begin{array}{l}\text { Trialability of electronic procurement } \\
\text { system }\end{array}$ & 4 & 0.7817 \\
\hline $\begin{array}{l}\text { Rate of Adoption } \\
\text { Saurce: }\end{array}$ & 4 & 0.7196 \\
\hline
\end{tabular}

Source: Field survey analysis, 2020

\section{Theoretical Framework and Model Specification}

The study's theoretical framework is premised on the Rogers' Diffusion of Innovations Theory (DIT). DIT is an explanation to the 
process of business enterprise members' adoption of a new technology. Rogers (2003:5) described innovation "as an idea, practice, or object that is perceived as new by potential adopters and which is considered as desirable to adopt." For Rogers, "an innovation is an instrumental action that is designed to reduce the uncertainty in the cause-effect relationships involved in achieving a desired outcome" (Rogers, 2003:13). The theory is very appropriate in investigating the adoption of innovation as it postulates and describes the stages, process, and rate new innovations spread through cultures that operate at the personal and organizational level. In the views of Rogers (2003), innovation, communication channels, time factor, and adoption among members within a social system are the primary mechanisms of the diffusion of innovations. These components assist in understanding the process of idea, practice, or object dissemination pertaining to innovations. Thus, the model for this study was developed based on the Rogers' diffusion of innovations theoretical framework, which is expressed as rate of adoption is a function of relative advantage, trialability, observability, complexity, and compatibility of electronic procurement system. It was therefore stated functionally as:

$\mathrm{RAD}=\mathrm{f}(\mathrm{RAE}, \mathrm{COE}, \mathrm{CME}, \mathrm{OBE}, \mathrm{TRE})$

Therefore,

$\mathrm{RAD}=\mathrm{a}_{0}+\mathrm{a}_{1} \mathrm{RAE}+\mathrm{a}_{2} \mathrm{COE}+\mathrm{a}_{3} \mathrm{CME}+\mathrm{a}_{4} \mathrm{OBE}+\mathrm{a}_{5} \mathrm{TRE}+\varepsilon$

Where: $\mathrm{RAD}=$ rate of adoption; $\mathrm{RAE}=$ relative advantage $\mathrm{COE}=$ compatibility; $\mathrm{CME}=$ complexity; $\mathrm{OBE}=$ observability; and $\mathrm{TRE}=$ trialability of electronic procurement system. $a_{1}, a_{2}, a_{3}, a_{4}$, and $a_{5}=$ coefficients of the independent variables; $\mathrm{a}_{0}=$ constant term; and $\varepsilon=$ error term.

Our apriori expectations were stated as: $a_{1}>0, a_{2}>0, a_{3}>0, a_{4}>0$, and $a_{5}>0$

\section{Findings and Discussion}

There are varying degrees of modalities to be put in place before the federal public hospitals in Edo State of Nigeria can adopt the EPS. Some of these modalities pose threats to the EPS adoption. In Table 
2 , the greatest challenge faced by the federal public hospitals and management staff according to the respondents in the EPS adoption was lack of EPS infrastructure due to inadequate funding. This factor was rated at mean value of 3.25. Most of the federal public hospitals are without the appropriate equipment and expertise to carry out EPS practices. This finding was supported by the research work of Matunga et al (2013) that the absence of innovative integration, technical issues with information technology, among others are the major difficulties confronted by many organizations in the course of e-procurement system implementation.

Table 2. Degrees of Difficulties Faced by the Federal Public Hospitals in the Adoption of EPS.

\begin{tabular}{|l|c|}
\hline \multicolumn{1}{|c|}{ Statements } & Mean \\
\hline $\begin{array}{l}\text { Management lacks vision of how to integrate } \\
\text { e-procurement system in the hospital }\end{array}$ & 1.59 \\
\hline $\begin{array}{l}\text { There is lack of e-procurement system } \\
\text { infrastructure due to inadequate funding. }\end{array}$ & 3.25 \\
\hline $\begin{array}{l}\text { The hospital lacks the ability to handle } \\
\text { change management. }\end{array}$ & 1.52 \\
\hline $\begin{array}{l}\text { There is slow pace to the training of } \\
\text { employees on how to use new innovations. }\end{array}$ & 2.42 \\
\hline $\begin{array}{l}\text { There is lack of suppliers' readiness to } \\
\text { implement joint e-procurement system } \\
\text { solutions with the hospital. }\end{array}$ & 3.01 \\
\hline $\begin{array}{l}\text { The hospital is uncertain as to the legality of } \\
\text { electronically sent documents. }\end{array}$ & 3.07 \\
\hline $\begin{array}{l}\text { Management lacks adequate } \\
\text { knowledge/technical expertise to operate the } \\
\text { electronic procurement system. }\end{array}$ & 3.15 \\
\hline $\begin{array}{l}\text { There is lack of security of e-procurement } \\
\text { transactions. }\end{array}$ & 3.11 \\
\hline $\begin{array}{l}\text { There is slow pace to uploading and } \\
\text { downloading of data due to network problem. }\end{array}$ & 2.27 \\
\hline $\begin{array}{l}\text { There is lack of confidentiality of information } \\
\text { sent through the e-procurement system }\end{array}$ & 1.41 \\
\hline
\end{tabular}

Source: Field survey analysis, 2020

Other noticeable difficulties faced by the federal public hospitals in EPS adoption were lack of adequate knowledge and technical 
expertise to operate the e-procurement system, lack of security of eprocurement transactions, uncertainty as to the legality of electronically sent documents, and lack of suppliers' readiness to implement joint e-procurement system solutions with the federal public hospitals. Possibly, the engagement of suppliers in the eprocurement system process may not be easily given the degree of their investment in different technological platforms, and complicity as a result of the use of digital languages. Based on the five-point Likert scale, these factors were rated at mean values of $3.15,3.11$, 3.07, and 3.01 respectively. This implies that staffs believe that these factors are of great concern to be surmounted before the EPS adoption in the hospitals can see the light of the day. Other less important challenges to the e-procurement system adoption identified by the respondents are the slow pace by the hospitals' management to the training of employees on how to use new innovations and slow pace to uploading and downloading of data due to network problem, as seen from the rating factors at 2.42 and 2.27 respectively based on five points Likert scale. The findings in this study are in line with the work of Matunga et al (2013) that the utmost difficulties confronted by public hospitals in Kenya in the course of e-procurement system adoption were inadequate funding and absence of training and development of staff on the use of innovative technology. They are of the view that some business enterprises consider the implementation of electronic procurement system as too expensive as well as the cost of training employees.

However, in the respondents' view, confidentiality of information sent through the e-procurement electronic platform, ability to take care of change management programs, and vision of how to integrate eprocurement practices in the hospitals, were of less possibility of posing challenges in the adoption of e-procurement system since these factors were rated at $1.41,1.52$, and 1.59 respectively on five points Likert scale. The finding in this study is inconsistent with the work of Davila et al (2003). Davila et al (2003) posited that resistance to change, absence of a generally accepted applications and leadership, are some of the utmost challenges to EPS adoption in the organizations. It was revealed in this study that the ability to handle change management programs was not a barrier to electronic procurement system adoption by federal public hospitals in Edo State 
of Nigeria. The hospitals have instituted cultural change prior to the acceptance of new innovations. The staffs were guaranteed of top management backing in order to effect any change. Senior management has ensured sufficient sensitization on the introduction of e-procurement system, which they believe will significantly lessen the resistance to the change. Also, confidentiality of the information sent through e-procurement system did not pose challenge to the federal public hospitals in Edo State of Nigeria in terms of eprocurement system adoption. This is opposing to the findings of Matunga et al (2013) that there was lack of confidentiality of the information sent by the hospitals.

Table 3: Degrees to Benefits of EPS Adoption.

\begin{tabular}{|l|c|}
\hline \multicolumn{1}{|c|}{ Statements } & Mean \\
\hline $\begin{array}{l}\text { E-procurement system reduces wastage of } \\
\text { time used in sourcing information. }\end{array}$ & 4.22 \\
\hline $\begin{array}{l}\text { E-procurement system reduces mistakes that } \\
\text { emanate from retyping and exchange of } \\
\text { documents. }\end{array}$ & 4.37 \\
\hline $\begin{array}{l}\text { E-procurement system results in lower } \\
\text { administration costs. }\end{array}$ & 3.64 \\
\hline $\begin{array}{l}\text { E-procurement system increases security of } \\
\text { procurement transactions }\end{array}$ & 4.19 \\
\hline $\begin{array}{l}\text { E-procurement system increases } \\
\text { accountability of business transactions. }\end{array}$ & 4.12 \\
\hline $\begin{array}{l}\text { E-procurement system increases efficiency of } \\
\text { business operations. }\end{array}$ & 4.08 \\
\hline $\begin{array}{l}\text { E-procurement system speeds the process of } \\
\text { selection of the right suppliers. }\end{array}$ & 3.81 \\
\hline $\begin{array}{l}\text { E-procurement system increases } \\
\text { transparency of availability of information for } \\
\text { goods and services. }\end{array}$ & 4.26 \\
\hline
\end{tabular}

Source: Field survey analysis, 2020

Table 3 shows that respondents indicated that e-procurement system results in reduction in mistakes that emanate from retyping and exchanging of documents, increased transparency of availability of information for goods and services, reduction in wastage of time used in sourcing information, increase in security of procurement transactions, increased accountability of business transactions, and 
increased efficiency of business operations. These are the major advantages of the adoption of EPS by respondents. These advantages were rated on a mean score of 4.37, 4.26, 4.22, 4.19, 4.12, and 4.08 on five points Likert scale respectively. Also, on high scales in terms of advantages of e-procurement system over the traditional system were the speedy process of selection of the right suppliers and lower administration costs resulting from the use of electronic procurement system, which were rated on a mean score of 3.81 and 3.64 , on five points Likert scale respectively.

This study is supported by works of Egbu, Vines and Tookey (2003), and Matunga et al (2013). Egbu et al (2003) asserted that the use of EPS reduces wastage of time in procurement process and mistakes that emanate from retyping and exchange of documents. Matunga et al (2013) stated that absence of accountability, transparency, improved operational efficiency, reduction in time spent in sourcing for information, and reduced costs of administration are the main traditional procurement issues, which can be taken care of by electronic procurement system adoption.

Table 4: Pearson's Correlation Coefficient for all Variables

\begin{tabular}{|c|c|c|c|c|c|c|c|c|}
\hline Variables & Mean & $\begin{array}{c}\text { Standard } \\
\text { Deviation }\end{array}$ & RAD & RAE & COE & CME & OBE & TRE \\
\hline RAD & 4.4117 & 0.7294 & 1.0000 & & & & & \\
\hline $\mathrm{RAE}$ & 4.4323 & 0.5945 & 0.5157 & 1.0000 & & & & \\
\hline $\mathrm{COE}$ & 4.1548 & 0.4301 & 0.3336 & 0.1339 & 1.0000 & & & \\
\hline $\mathrm{CME}$ & 2.2969 & 0.1935 & -0.6284 & -0.3445 & -0.5152 & 1.0000 & & \\
\hline $\mathrm{OBE}$ & 3.4884 & 0.2285 & 0.2532 & 0.6941 & 0.3823 & 0.5317 & 1.0000 & \\
\hline $\mathrm{TRE}$ & 3.7775 & 0.3167 & 0.1928 & 0.5018 & 0.4415 & 0.6452 & 0.3371 & 1.0000 \\
\hline
\end{tabular}

Source: Field survey analysis, 2020

In Table 4, the values of correlation statistics were all positive except the value of complexity. This indicates that the exogenous variables with the exception of complexity variable move in the same way as rate of adoption of EPS in the healthcare sector of Nigeria. It shows that the electronic procurement system rate of adoption is significantly and positively correlated with the independent variables 
at five per cent degree of significance with the exception of complexity variable. It was also observed that the exogenous variables in relation to rate of adoption of e-procurement system did not display multicollinearity since the variables do not have correlation values in excess of 0.90 (Dwivedi, 2008).

The means of the five characteristics of e-procurement system adoption based on Rogers' diffusion of innovations approach: relative advantage, observability, complexity, compatibility, and trialability of the innovation are shown in Table 4. The Table reveals that management staff of Federal public hospitals in Edo State of Nigeria emphasized more on relative advantage of the use of the technology as it affects rate of its adoption (mean $=4.4323$ ). The least emphasis was on complexity of the use of the technology as it affects rate of its adoption (mean $=2.2969$ ). This indicates that respondents are of the view that innovations that are difficult and non-user-friendly in design should be disregarded. Thus, simpler innovations in terms of its understanding will be quicker to adopt by the employees of these organizations. The mean score value for the five characteristics of eprocurement system adoption was equal to 3.6299. Based on the fact that the measure used a five-points Likert scale, it can be inferred that Federal public hospitals in Nigeria is highly committed to the adoption of e-procurement system attributes premised on Rogers' diffusion of innovations theory approach above the average value of the mean. The mean of the rate of adoption in federal public healthcare industry is also shown in Table 4. The Table reveals that federal public healthcare industry has a high rate of adoption of eprocurement system with a mean of 4.4117 . Been that the measure used a five-points Likert scale, it can be decided that federal public healthcare industry in Edo State of Nigeria has a high rate of adoption of e-procurement system above the mean value of 3 .

Table 5: Regression Analysis based on OLS Estimation Technique

\begin{tabular}{|c|c|c|c|c|c|}
\hline Variable & $\begin{array}{c}\text { Coefficien } \\
\mathbf{t}\end{array}$ & $\begin{array}{c}\text { Standard } \\
\text { Error }\end{array}$ & $\begin{array}{c}\text { t- } \\
\text { Statistics }\end{array}$ & P-value & Hypotheses \\
\hline $\mathrm{RAD}$ & 14.2398 & 6.1309 & 2.3225 & 0.0000 & Significant \\
\hline $\mathrm{RAE}$ & 9.0941 & 3.4692 & 2.6214 & 0.0000 & Significant \\
\hline $\mathrm{COE}$ & 8.9372 & 3.5968 & 2.4846 & 0.0000 & Significant \\
\hline $\mathrm{CME}$ & -2.3427 & 0.9801 & -2.3903 & 0.0005 & Significant \\
\hline
\end{tabular}


Employee Perceptions of the Electronic Procurement System (EPS) and Rate of Adoption of EPS by the Federal Public Hospitals in Edo State of Nigeria Based on the Diffusion of Innovations Theory

\begin{tabular}{|c|c|c|c|c|c|}
\hline OBE & 4.6372 & 1.9321 & 2.4001 & 0.0002 & Significant \\
\hline TRE & 7.6389 & 3.1811 & 2.4012 & 0.0001 & Significant \\
\hline $\begin{array}{l}\mathrm{R}^{2}=0.8817, \text { Adjusted } \\
\text { Watson }=1.9186\end{array}$ & $\mathrm{R}^{2}=0.8452$, F- Stat (Prob.) $=34.0051[0.0000]$, Durbin \\
\hline
\end{tabular}

Source: Field survey analysis, 2020

The estimated multiple regression model results are depicted in Table 5. The R-squared value of 0.8817 shows that relative advantage, compatibility, complexity, observability, and trialability of the innovation, jointly explain 88.17 per cent of the systematic variations in the rate of adoption of electronic procurement system in the federal public hospitals sector of Edo State of Nigeria. This indicates that only 11.83 per cent is accounted for by other exogenous variables, which were not captured in the study. The R-Bar squared value of 84.52 per cent, which is reasonably high, further supported the result of the Rsquared value. This implies a goodness of fit for the model.

The F-Statistics of 34.0051 with probability score of 0.0000 shows that there was a simultaneous linear association between the dependent variable and the exogenous variables joined together. This indicates that the combined effects of the identified exogenous variables in the model were substantial in explaining the rate of adoption of e-procurement system in the Federal public hospitals sector of Edo State of Nigeria. The Durbin Watson statistic value of 1.9186 is sufficiently close to 2 . This implies that the outcomes of this study are very sound for policy adoption of e-procurement in the federal public hospitals in Edo State.

From Table 5, the result of the research also showed that all the factors significantly and positively influenced Federal public hospital management and staff members' likelihood of adopting e-procurement system into their mode of operations except the complexity of technological innovation which has a significant but negative impact on the rate of adoption of electronic procurement system in the federal public hospitals. When we equate the independent variables calculated t-values of 2.6214, 2.4846, 2.4001, and 2.4012, respectively with the t-table value of 2.39 at five (5) percent level, indicate that a unit increase in RAE, COE, OBE, and TRE will result in an increase in RAD of Federal public hospitals, Edo State of Nigeria 
by $9.0941,8.9372,4.6372$, and 7.6389 units respectively. In the same vein, comparing the independent variable of the calculated t-value of -2.3903 with the $t$-table value of 2.39 at five percent level, shows that a unit increase in CME will result in a decrease in RAD of Federal public hospitals, Edo State of Nigeria by 2.3427. This is in line with Rogers (2003) that complexity has a negative correlation with the rate of adoption of innovation. Thus, unnecessary difficulty in the use of an innovation is a vital challenge to the adoption of such technology. This is as a result of several technicalities that are usually involved in designing the technology. Hence, management and staff members with the challenge of integrating the electronic procurement system innovation into their mode of operations are encouraged to be trained in the art of Information and Communication (ICT) and related tools.

Furthermore, considering the strength to which the exogenous variables affect the dependent variable in Table 5 , the coefficient results showed that relative advantage in the use of e-procurement system has the most significant effect on management staff of the hospitals' rate of adoption of e-procurement system $\left(a_{1}=9.0941\right.$, $\mathrm{p}<0.05$ ), and complexity of the e-procurement system has the least significant effect on management staff of the hospitals' rate of adoption of electronic procurement system $\left(\beta_{3}=2.3427, \mathrm{p}<0.05\right)$. Hence, relative advantage of the use of EPS is the most significant predictor of the rate of adoption of e-procurement system by management staff of Federal public hospitals in Edo State of Nigeria. Indeed, the perception of relative advantage of the use of EPS adoption by management staff of federal public hospitals in Edo State of Nigeria as having greater value in improving the operational efficiency than the traditional procurement system has a greater chance in the rate of adoption of the electronic procurement system.

\section{Conclusions}

The study assessed the perception of EPS and rate of adoption in the federal public hospitals in Edo State of Nigeria based on Rogers' diffusion of innovations approach consisting of: relative advantage, complexity, compatibility, observability, and trialability. After a deep analyses and evaluation of the challenges and advantages of the adoption of the EPS, lack of the EPS infrastructure due to inadequate funding and inadequate knowledge and technical expertise to operate the EPS were the greatest challenges faced by the hospitals and 
management staff of the federal public hospitals in Edo State of Nigeria. The advantages of the adoption of the EPS, according to this study are: reduction in errors emanating from retyping and exchange of documents, increased transparency of availability of information for goods and services, and increased efficiency of business operations. Rogers' diffusion of innovations approach on the viewpoints of organizations to accept innovations, the study concluded that relative advantage of e-procurement system was the more appropriate factor of the features of innovations that influenced the rate of federal public hospitals in Edo State of Nigeria's adoption of innovations.

Thus, the study contributed to the EPS adoption literature as a way to examine the effect of each dimension of characteristics of process innovations on rate of adoption in the federal public hospitals in Edo State of Nigeria. Second, it used Rogers' diffusion of innovations approach to analyze the relationship between the EPS and rate of adoption. It pointed out the importance of determining the characteristics of process innovations that should be highly embraced in enhancing the rate of adoption of the EPS in organizations. The study showed that a number of successes have been adduced to the adoption of the e-procurement system. With the swift changes to the adoption of the EPS by organizations, it is critical for federal public hospitals in Edo State of Nigeria to "move along with time" by changing their business strategy in order to remain relevant and competitive in this modern time.

In order to reap the full benefits of EPS by the federal public hospitals in Edo State of Nigeria, the following recommendations are proposed based on the findings of the study:

i). federal public hospitals in Edo State of Nigeria should brace up effort in the adoption and use of e-procurement innovation. The swift policy strategy in the adoption of EPS is critical for them to move with the trend of time not only to remain successful but also to sustain competition.

ii). there should be simplicity in the design of new innovations. Simpler the innovation, quicker the adoption by the employees of the organizations. 
iii) innovations should be demonstrable. Innovations that are easily verifiable represent more of certainty by the employees who will accept it for adoption. The more an innovation is experimented in the course of proving the workability, the sooner its adoption since employees could learn during the process of trialability.

iv). government should promulgate necessary policies/laws that will boost stakeholders (suppliers, clients, among others) confidence towards certainty that electronically sent documents and business transactions of EPS is recognized as valid and legal by a third party.

v). management of the hospitals' procurement departments should deploy the necessary ICT infrastructure, trained personnel with requisite expertise, digital skills, and knowledge. These are very pertinent to the successful and smooth adoption of an electronic procurement system.

vi). the necessary change management should be deployed to change the psyche of the old staffs that have not braced up with the advancement in innovative technology and e-procurement initiative. They form the majority of those against change management programs with the belief that there is difficulty in keeping pace with something new from the training they already have.

vii). due to the several technicalities involved in managing new innovations, e-procurement system innovations that are user-friendly should be adopted.

viii). on the issue of suppliers not being ready to use new innovation, management should build good business synergy with suppliers on the need to key into the trend of e-procurement system.

ix). to enable smooth business transactions with suppliers, management should ensure that the right consultants be made to design the e-procurement system with the appropriate security aperture put in place to avoid hacking into the organizational database.

\section{References}

Beatty, R.C., Shim, J.P., \& Jones, M.C. (2001). Factors influencing corporate web site adoption: A time-based assessment. Information \& Management Journal, 38(6), 337-354. https://doi.org/10.1016/S0378-7206(00)00064-1 
Bodunrin, A.K. (2016). Empirical review and analysis of public procurement practices in Nigeria: Challenges and prospects. Public Policy and Administration Research, 6(3), 128-135.

Davila, A., Gupta, M., \& Palmer, R. (2003). Moving procurement systems to the internet: The adoption and use of e-procurement technology models. European Management Journal, 21(1), 1123. https: / / doi.org/10.1016/S0263-2373(02)00155-X

Dibra, M. (2015). Rogers theory on diffusion of innovation: The most appropriate theoretical model in the study of factors influencing the integration of sustainability in tourism businesses. Proceedings of Social and Behavioral Sciences, 1453-1462. doi: 10.1016/j.sbspro.2015.06.443

Dwivedi, D.N. (2008). Managerial economics. New Delhi: Vikas Publishing House PVT Limited. https://bok.cc/book/3570906/dfa93d

Egbu, C., Vines, M., \& Tookey, J. (2004). The role of knowledge management in e-procurement initiativesm for construction organizations. ARCOM Proceedings, Herriot Watt University, Scotland, 661-671. https://www.semanticscholar.org/paper/

Ikponmwosa, N., \& Omoregbe, O. (2018). Efficiency of healthcare companies in Nigeria: A data envelopment analysis. Journal of Economics and Development Studies, 6(1), 235-250.

Matunga, D.A., Nyanamba, S.O., \& Okibo, W. (2013). The effect of eprocurement practices on effective procurement in public hospitals: A case of Kisii level 5 hospital. American International Journal of Contemporary Research, 3(8), 103-111.

Min, H., \& Galle, W.P. (2003). E-purchasing: Profiles of adopters and non-adopters. Industrial. Marketing Management, 32, 227-233. https://doi.org/10.1016/S0019-8501(02)00266-3

Minahan, T., \& Degan, G. (2001). Best practices in e-procurement. Boston: Aberdeen Group.

Nunnally, J., \& Bernstein, I. (1994). Psychometric theory. New York: McGraw-Hill.

Ojo, A.E. \& Gbadebo, A.M. (2014). An assessment of non-compliance with procurement proceedings in procurement of works in 
Nigeria. International Journal of Economic and Business Management, 2(3), 25-34.

http://www.academicresearchjournals.org/IJEBM/Index.htm

Robinson, L. (2009). A summary of diffusion of innovations. Available at:http://www.enablingchange.com.au/Summary_Diffusion_ Theory.pdf

Rogers, E.M. (2003). Diffusion of innovations. New York: Free Press.

Sahin, I. (2006). Detailed review of Rogers' diffusion of innovations theory and educational technology-related studies based on Rogers' theory. The Turkish Online Journal of Educational Technology, 5 (2), 14 -23.

Trkman, P., \& McCormack, K. (2010). Estimating the benefits and risks of implementing e-procurement. IEEE Transactions on Engineering Management, 57(2), 23-37. http://doi.org/10.1109/TEM.2009.2033046.

Vaidya, K., Sajeev, A. S. M.. \& Callender, G. (2006). Critical factors that influence e-procurement implementation success in the public sector. Journal of Public Procurement, 6(1\& 3), 70-99. https://doi.org/10.1108/JOPP-06-01-02-2006-B004.

Wu, F., Zsidisin, G.A., \& Ross, A. (2007). Antecedents and outcomes of e-procurement adoption: An integrative model. IEEE Transactions on Engineering Management, 54(3), 576-587. https://doi.org/10.1109/TEM.2007.900786. 